\title{
10
}

\section{We hear you! Case studies in authentic civic engagement from the City of Melbourne}

\section{Stephen Mayne}

This contribution to the present volume follows on from Dominik Hierlemann's earlier reflections on Germany's Citizens' Forum (Chapter 10). The City of Melbourne recently held a similar civic engagement experiment in public policymaking in the form of a citizen jury to help formulate our first-ever 10-year financial plan.

First, some background. At the City of Melbourne, we claim to be the most open and transparent local council in Australia. Some of the things we have done to justify this boast include fully disclosing our lease register and our individual land valuations. We also disclosed the contracts of our top six executives: their start date, their end date, what they are paid and so on. Moreover, we have a conflict of interest register on our website. Every time a councillor declares a conflict of interest for a political donation, it appears on the register. And we disclose, quarterly, all our expenses. Examples include public pre-approval of all interstate and international travel.

We also try and maintain a transparent decision-making process, with most of our tenders done in open session. To this end, we also allow public questions at the beginning and the end of every committee meeting: twice a month we have unscripted oral public questions, with no warning or 
notice. Audio of all council meetings and committee meetings is put online. As are all submissions from the community, so we can see what everyone else is saying. And we allow the community to participate in every single resolution at committee. They can submit 10 times in the one night on all different planning applications, if they wish, and then their submission is on the website as audio and a written submission on the website for everyone to see.

We still have a few things to achieve with regards to transparency. We are yet to work up a 10-year capital works program with detail so residents can see the individual projects: what are we spending in 2021-22, for instance. We need to be more open and transparent with our enterprise agreement. I would love to do a citizen jury on that. There has never been one done in Australia on enterprise agreements. And I would love to get councillors to admit how many free tickets we get to events. My colleagues have been very agreeable so far on transparency, but they don't all share my views on this specific issue. I may have to do that one just before the next election and embarrass them into admitting that we should disclose all free tickets that we receive to events. Because there is a lot of them.

\section{Formulating a 10-year plan}

The authorising environment for our first citizen jury was a community engagement framework. We have a council plan with eight goals listed in it, a declaration of the council values and then our vision statement to be 'bold, inspirational and sustainable'. It was at the start of the last council that we put in that aim to be Australia's most open and transparent council. In terms of our 10-year financial plan, we previously didn't have one. And one of the things about citizens' juries, as mentioned by Dominik Hierlemann in this volume, is that we have to give them real power. We cannot simply make a decision and then ask for retrospective approval. We have to put a decision on the line and let the community decide.

And so, having never formulated a 10-year financial plan, we decided to let the community have the first go. And because we had no previous such financial plan, there was no defence of the status quo among our councillors. There was no policy at all. In fact, previously in this area there had been very little transparency. We just had an annual budget. We did have a four-year forward estimate, but it was not very detailed. 
So, the 10-year plan represented a new piece of disclosure and forward planning. We could have pursued the New York model of 'let's let them decide $\$ 2$ million worth of grants in a ward'; that approach is easy: put a small bit of money on the table and let the community talk about a few visible projects like a new park and that sort of thing. But we thought we would get the community to start with their plan. That is a far more complex procedure.

To give readers an idea of numbers involved, our annual budget is around $\$ 430$ million a year. We hold $\$ 4.5$ billion in assets, and employ 1,200 staff. We have to spend $\$ 700$ million on open space in the next 10 years. We are going to spend $\$ 250$ million on the Queen Victoria Market—at 18 acres, the world's biggest open-air market. How are we going to fund it and not jack the rates up too much? We wanted to hear what the citizens' forum thought. One of the problems is that we are currently over-dependent on car parking revenue, from which we make $\$ 100$ million per year. But, given the rapid changes to transportation, be it carpooling or driverless cars, this may fall in the future, meaning we need to diversify our revenue sources.

Consider some of the drivers of our 10-year financial plan. In the 2014-15 financial year, the City of Melbourne had the fastest growing population out of Australia's 560 councils. On the ground, this means massive density, massive apartment approvals and strong immigration. Melbourne, along with London, New York and Paris, is one of the world's four biggest cities for international students. The challenge of this amazing growth for us, the capital city council, is how we are going to manage and finance it.

By way of comparison, Sydney's Barangaroo redevelopment covers around 20 hectares. We have a couple of hundred hectares of urban renewal space when you combine Fishermans Bend, Arden-Macaulay and the rest of Docklands. These areas represent a lot of infill: former industrial areas with high density and strong growth. It is our job to manage the finances around it.

The Economist (2017) has declared Melbourne the world's most lovable city for the last seven years. How do we retain that title? We first asked our citizen jury. Next, more specifically, council officers put on the table that we were $\$ 900$ million short in terms of our long-term projections of delivering infrastructure. At the time that was a controversial number from the administration because the Lord Mayor himself didn't believe it was true. 
But this controversy was also a strength: the officers had to come up with a position. Previously, no one had said what the infrastructure shortfall was-because no one had ever asked or calculated it. We said to the officers we were getting 43 ordinary citizens to formulate a 10 -year financial plan, and we wanted the officers to tell them what they thought the shortfall was. The officers had to dig their way through their spreadsheets and come up with a number that the Lord Mayor disputed. The fact that we had a jury deciding our policies for the next 10 years shows how successful the process is in eliciting much new information. It was a comprehensive engagement process. We had pop-ups, we had surveys, we had budget simulators. We conducted significant, preliminary engagement before we empanelled our 43 panellists.

\section{The engagement process}

How did we select them? We said we would have 50 per cent from our business electoral franchise and 50 per cent from our residential electoral franchise. In hindsight, the category that we omitted was the 700,000 people who visit the city every day: the workers, the international visitors - we did not give them a say. Perhaps that was why many of the recommendations that emerged were very anti-car, because we did not have anyone on the panel who was driving in or stuck in traffic, day after day.

We went for our voting franchises, which is people, residential and business, who could vote. We ensured that we had good diversity so we engaged with the universities to make sure we got lots of students involved, because 42 per cent of the residents in the City of Melbourne are students. We also went for diversity in geography, business, residential status, age and gender.

I have already mentioned the online budget simulator but not yet the funnel approach, whereby we presented the panel with a wad of research and feedback from what the community was already saying about our financial challenges before they even sat down. Using our online simulator, anyone can move a dial to indicate whether they support spending more on events and less on community services. That gave us some more interesting feedback, which we gave to the panel. 
The panel was then assisted by the New Democracy Foundation, which is funded by Luca Belgiorno-Nettis, whose father was one of the founders of Transfield. He has donated about $\$ 5$ million to the foundation because he believes the political system is broken, and that citizen juries are the way to make public policy. From our experience, I agree with him. There is a massive trust deficit for local government; the community thinks we are all hopeless and conflicted and corrupt. Because of this, it is wonderful to randomly select a jury, instead of engaging the usual suspects of squeaky wheels banging on, privileged rent seekers and those who know which buttons to push.

Moreover, our randomly selected jurors were committed. Over six full Saturdays - sunny Saturdays, too-they showed up. By the end, we thought we would be down to 30 participants, but we still had 43 . They loved the fact that there was real policy on the line. They loved the fact that they could choose the topics and speakers, who they nominated by name. When they asked us about demography, for example, they requested News Corp social commentator Bernard Salt to speak to them and he did. When they told us they wanted to hear more about climate change from Monash University Professor Graeme Pearman, we invited him too.

It was up to participants to decide in which direction the process went. After the initial presentations from City of Melbourne officers, the panel then chose what they wanted to hear. They told us they wanted to hear from the planning minister. They picked the topics and we councillors had little influence-we were not allowed to intervene unless requested. The sessions were open to observers more than 90 per cent of the time, but only New Democracy and the facilitators from Mosaic Lab were allowed to attend all the sessions. Residents' groups were initially furious, but slowly came around as they came to watch a few sessions and were allowed to observe most of it, without ever campaigning or participating. There was a feedback board for written comments and suggestions, but we explained to them that no outside influences were permitted - as with a legal jury. For the same reason, the media were allowed to some sessions, but not the deliberative ones.

Council is a very complex beast, with five key service streams, meaning we had to explain to the citizen jury all the things we do. It was thus a huge task to get the community - with no initial knowledge - to understand the full complexity and diversity of a capital city council. And, in hindsight, 
it was probably almost too big a challenge in terms of getting people up to speed with all the details of what councils do. We also had to deliver them rates modelling and how we measure infrastructure spendings.

\section{Outcomes}

So what were the practical outcomes of this process? We all learnt so much from this amazing sharing and first-time disclosure of all this new information. The panel of citizen jurors made 11 recommendations. Melbourne City Council held a special committee meeting to receive the panel report and then we agreed to consider it more thoroughly; we adopted our first-ever 10-year plan on 30 June 2015. Moreover, we embedded the full panel report in our 10-year financial plan. And we made our officers explain their decisions behind implementing — or notparticular recommendations.

The panel was delighted because there was a very strong adherence in the 10 -year plan to their recommendations. For example, I wanted to sell Citywide, the services company that we own — quite a big business, with $\$ 200$ million in revenue. They panel said no. I thanked them, deferred to their decision and said we would not privatise Citywide. Instead, we are taking up their suggestion to review our property portfolio, as well as cranking up our developer contributions.

The City of Sydney has been making almost $\$ 100$ million a year from developers in recent times. We have probably made $\$ 50$ million in 20 years. We are severely under-taxing the developers. Consequently, we have now effectively doubled the revenue we are getting from open space contributions from developers. Normally, such a move would have been resisted by the Liberals and a few others, but because it was the citizen jurors who argued for this decision, it was passed unanimously a few weeks after the panel made their recommendations. They have delivered real influential outcomes.

Two more examples of this: we are cranking up our spending on renewables and sustainability because the panel said we should do it and we are going after car parking because they said we are too reliant on it, and we needed to get more cars out of the city. Two weeks after they said that, we established 20 car-free bays for motorcycles. We simply converted them from car to motorcycle use and sustained the resulting revenue loss. I was able to get that initiative passed by pointing out that it was a panel recommendation. 
The citizen jury received positive media coverage, especially from $\mathrm{ABC}$ Radio National (Ryan 2015) and The Age (Reece 2015). Yes, some of the tabloid media, the Herald Sun among them (Reece 2014), attacked it at first. This is in part because they are privileged influences too: they like to be able to ring the Lord Mayor; they like to be able to write editorials that tell politicians how to behave.

But they changed their view when they realised we were involving real people-people who read the Herald Sun-who would tell us what to do. That argument tended to neutralise the critique that councillors are outsourcing their job because they cannot do it themselves-a popular accusation levelled at Julia Gillard when she announced her desire to hold a citizens' jury on climate change just before the 2010 election. She was heavily criticised for the perception she was copping out on a policy position where Labor was fully invested by trying to outsource it to a panel.

Finally, we did some research with the panellists under the auspices of the University of Melbourne. The panellists are now our biggest advocates. They go around telling people how great the City of Melbourne is. They say that they are very satisfied with democracy at the city council. Onethird of them say they are much more interested in politics than they were previously. New Democracy has told us that, on average, one-third of participants in citizen juries end up then volunteering for something else because they have become engaged through the process. In other words, they have become civically stimulated.

People love to volunteer not only because they receive a gold embossed invitation from the Lord Mayor that looks like a royal wedding invitation, but because they love the fact that it is a finite commitment. You are not secretary of your local tennis club for life-you are volunteering for five or six Saturdays and then you can get on with your life. There is no ongoing commitment. So we were surprised that 700 of the 7,000 people we randomly wrote to agreed to give us five or six Saturdays of their time even though we would pay them under-award wages of $\$ 500$ for the whole five days. The finiteness of their contribution was an important reason so many people agreed to be part of the process.

For local government, I think the citizens' jury experiment has been a great success. We need to become more transparent. We need to have more easy access to information. I think we should do more of these citizen juries for vexed policy decisions where there are trade-offs. They are great for 
trade-off decisions. I would love, for example, to do one on our enterprise agreement, which is 99 pages and has 1,041 clauses. But so far I have had no success in that endeavour, with the typical response being you can't talk about that'. The challenge with the citizen jury is to do it in a scaled way and keep the cost down per project. We spent $\$ 182,000$ on ours. And though we would love to roll them out at short notice on various issues, they are very face-to-face, intensive, time-consuming and costly. These are all challenges for the model of citizens' juries.

It would be great to develop some sort of a model that can be scaled at a reasonable cost, because in an era of massive loss of trust, I am a huge fan of citizens' juries. Panels have now been tried all over Australia and they generally get it right. It is rare for a panel, after a deep dive, to come out with a stupid recommendation. It is amazing how smart the community is when you randomly select them. If you safeguard it with an 80 per cent super majority requirement, meaning nothing is approved unless it is positive and popular, and you put a real decision on the line, it is amazing how smart panellists are. To conclude, in light of the City of Melbourne's experience, I would recommend citizens' juries as a policymaking tool for all levels of government. Yes, you have to give up some power. Yes, it is a risk. But from our experience, it has worked very well.

\section{References}

The Economist. 2017. 'Global Liveability Has Improved for the First Time in a Decade'. 16 August. Available from www.economist.com/blogs/ graphicdetail/2017/08/daily-chart-10

Reece, N. 2014. 'Putting People Power Back into Democracy'. 1 September, The Age.

Reece, N. 2015. 'Melbourne’s Democracy Experiment Pays Off'. 29 June, The Age.

Ryan, R. 2015. 'Melbourne Citizens' Jury Success Offers Fresh Hope for Democratic Renewal'. 3 July, ABC Radio National. Available from www.abc.net.au/radionational/programs/sundayextra/citizens-jurysuccess-offers-fresh-hope-for-democratic-renewal/6589630 
This text is taken from Opening Government: Transparency and Engagement in the Information Age, edited by John Wanna and Sam Vincent, published 2018 by ANU Press, The Australian National University, Canberra, Australia.

doi.org/10.22459/OG.04.2018.10 